\title{
Isolated Abducens Nerve Palsy in Multiple Myeloma With Hyperviscosity of the Serum
}

\author{
Hiromasa Tsuda ${ }^{\mathrm{a}, \mathrm{d}}$, Noriko Doki ${ }^{\mathrm{b}}$, Kazuteru Ohashi ${ }^{\mathrm{b}}$, Morihiro Inoue ${ }^{\mathrm{c}}$, \\ Masao Hagihara ${ }^{c}$, Kozue Tanaka ${ }^{a}$
}

\begin{abstract}
A 40-year-old woman without contributory medical history was diagnosed as having IgA type multiple myeloma, based on the immunological and pathological investigation. Blood pathology demonstrated the rouleaux formation. Then, sudden onset of left-sided complete abducens nerve palsy (6NP) without pain was preceded to initiation of chemotherapy. Cranial and orbital magnetic resonance imaging, and cerebrospinal fluid examination demonstrated no abnormalities. Under chemotherapy, 6NP was resolved within 5 weeks. This is a first reported case of multiple myeloma presenting with $6 \mathrm{NP}$ without intracranial lesion. We speculated that $6 \mathrm{NP}$ might be caused by peripheral ischemia due to hyperviscosity of the serum.
\end{abstract}

Keywords: Cranial sixth nerve; Ophthalmoplegia; Rouleaux formation

\section{Introduction}

Multiple myeloma (MM) is a plasma cell malignancy characterized by monoclonal expansion of lymphoplasmacytic cells in the bone marrow. In MM, abducens nerve palsy

\footnotetext{
Manuscript accepted for publication August 13, 2012

${ }^{a}$ Department of Neurology, Tokyo Metropolitan Cancer and Infectious Diseases Center Komagome Hospital, 3-18-22, Honkomagome, Bunkyo-ku, 113-8677, Tokyo, Japan

${ }^{\mathrm{b}}$ Department of Hematology, Tokyo Metropolitan Cancer and Infectious Diseases Center Komagome Hospital, 3-18-22, Honkomagome, Bunkyo-ku, 113-8677, Tokyo, Japan

${ }^{c}$ Department of Hematology, Eiju General Hospital, 2-23-16, Higashiueno, Taito-ku, 110-8645, Tokyo, Japan

${ }^{\mathrm{d} C o r r e s p o n d i n g ~ a u t h o r: ~ H i r o m a s a ~ T s u d a, ~ D e p a r t m e n t ~ o f ~ N e u r o l o g y, ~}$ Tokyo Metropolitan Cancer and Infectious Diseases Center Komagome Hospital. 3-18-22, Honkomagome, Bunkyo-ku, 113-8677, Tokyo, Japan. Email: hiromasatsuda@cick.jp

doi: http://dx.doi.org/10.4021/jmc855w
}

(6NP) may be usually caused by its invasion to the clivus [1, 2] or intracranial plasmacytoma [3-11]. Here, we describe a case of MM presenting 6NP without intracranial lesion, which might be associated with hyperviscosity of the serum (HV).

\section{Case Report}

A 40-year-old Japanese woman without contributory medical history was admitted to a hospital because of acute bacterial pneumonia in December 2011. Under antibiotic therapy, pneumonia was resolved within 5 days. However, complete blood cell count revealed severe anemia (a hemoglobin of $7.7 \mathrm{~g} / \mathrm{dL}$ and MCV at $91.7 \mathrm{fL}$ ), platelet count at $22.8 \times 10^{3} /$ $\mu \mathrm{L}$, white blood cell count at $5,200 / \mu \mathrm{L}$, and absolute neutrophil count at $3,740 / \mu \mathrm{L}$. Blood pathology demonstrated the rouleaux formation. Blood chemistry demonstrated normal findings. On the serum immunological examination, marked elevatedIgA level at $3,526 \mathrm{mg} / \mathrm{dL}$ was observed, despite decreased IgG at $534 \mathrm{mg} / \mathrm{dL}$, and IgM at $35 \mathrm{mg} / \mathrm{dL}$. On the immunoglobulin free light chain, $\lambda$ type at $1,180 \mathrm{mg} / \mathrm{L}$ and $\kappa$ type at $6.4 \mathrm{mg} / \mathrm{L}$ were observed. In the urinary study, Bence Jones protein was detected. Bone marrow aspiration examination demonstrated that plasmacyte was occupying $38.6 \%$. As a result, the patient was diagnosed as having $\operatorname{IgA} \lambda$ type MM. Based on a clinical staging system [12], the patient's clinical stage was IIIA. However, there was no bone involvement. Three days later, the patient abruptly developed left complete 6NP. Funduscopic examination demonstrated no abnormalities in either eye. Neither coujunctival injection and chemosis, nor periorbital edema was observed. There were no eruption in her face and head. The diameter of the pupil was $3 \mathrm{~mm}$ in both eyes in the lightened room. Pupil responses to light and near were prompt in either eye. Palpebral aperture measured $9 \mathrm{~mm}$ bilaterally. Proptosis, lid retraction, lid twitch, enhanced ptosis, and fatiguable ptosis were not observed in each eye. Thyroid function was within normal ranges. Electrocardiogram and chest radiograph examination demonstrated normal findings. Cranial and orbital MR imaging as well as cranial MR angiography demonstrated no abnormalities. Cerebrospinal fluid examination dem- 
onstrated that cell count was $1 / \mu \mathrm{L}$ (all was mononucleocyte), protein concentration at $22 \mathrm{mg} / \mathrm{dL}$, and glucose at $54 \mathrm{mg} /$ $\mathrm{dL}$. The cytology of cerebrospinal fluid did not demonstrated malignant cell. Thereafter, by administration of bortezomib and dexamethasone therapy, left 6NP, anemia and serum immunoglobulin level were normalized within 5 weeks.

\section{Discussion}

The abducens nerve is running pieces the dura of the clivus, passes through the Dorello's canal formed by the petroclinoid ligament, and then enters the cavernous sinus. This nerve exits the cavernous sinus through the superior orbital fissure and innervates the lateral rectus muscle. Consequently, in $\mathrm{MM}$ case of $6 \mathrm{NP}$, this nerve may be damaged by its invasion to the clivus $[1,2]$ or intracranial plasmacytosis [3-11].

HV may cause not only cerebral infarction $[13,14]$ but also vasculopathic ocular motor nerve palsy [15]. Patients with a vasculopathic 6NP usually have complete resolution. The presumed mechanism of vasculopathic ocular motor nerve palsy involves thickening and hyalinization of nutrient vessels, which results in ischemic demylinization of a portion of the nerve $[16,17]$. Following infarction and demyelination of the cranial motor nerve, the area of ischemic demyelination subsequently undergoes remyelination over time, thus accounting for spontaneous recovery $[16,17]$.

$\mathrm{HV}$ is commonly observed in patients with IgA myeloma [18]. In our present patient, HV was confirmed by the rouleaux formation, and complete 6NP developed suddenly, and disappeared within 5 weeks. She did not have other risk factors for ischemic 6NP, such as diabetes mellitus, hypertension, hyperlipidemia and smoking habit. Therefore, we believed that HV might cause ischemic 6NP.

In conclusion, this is a first reported case of 6NP due to MM without intracranial lesion, which may be caused by HV.

\section{Conflicts of Interest}

No conflict of interest exists.

\section{References}

1. Kanemura N, Tsurumi H, Hara T, Yamada T, Sawada M, Moriwaki H. [Multiple myeloma complicated by bilateral abducens nerve palsy due to a tumor in the clivus]. Rinsho Ketsueki. 2001;42(3):218-220.

2. Na JH, Park SH, Shin SY. Multiple myeloma manifesting as a fluctuating sixth nerve palsy. Korean J Ophthalmol. 2009;23(3):232-233.
3. Chin KJ, Kempin S, Milman T, Finger PT. Ocular manifestations of multiple myeloma: three cases and a review of the literature. Optometry. 2011;82(4):224-230.

4. Fung S, Selva D, Leibovitch I, Hsuan J, Crompton J. Ophthalmic manifestations of multiple myeloma. Ophthalmologica. 2005;219(1):43-48.

5. Kashyap R, Kumar R, Kumar S. Cranial nerve palsy in multiple myeloma and solitary plasmacytoma. Asia Pac J Clin Oncol. 2010;6(4):251-255.

6. Higurashi M, Yagishita S, Fujitsu K, Kitsuta Y, Takemoto Y, Osano S. Plasma cell myeloma of the skull base: report of two cases. Brain Tumor Pathol. 2004;21(3):135141.

7. Movsas TZ, Balcer LJ, Eggenberger ER, Hess JL, Galetta SL. Sixth nerve palsy as a presenting sign of intracranial plasmacytoma and multiple myeloma. J Neuroophthalmol. 2000;20(4):242-245.

8. Smyth A, Murphy SM, Counihan TJ. An unusual cause of cavernous sinus syndrome. BMJ Case Rep. 2009;2009.

9. Cockerell OC, Kapoor R. Cranial neuropathy. Postgrad Med J. 1997;73(861):441-442.

10. Yaman E, Benekli M, Coskun U, Sezer K, Ozturk B, Kaya AO, Yildiz R, et al. Intrasellar plasmacytoma: an unusual presentation of multiple myeloma. Acta Neurochir (Wien). 2008;150(9):921-924; discussion 924.

11. Neki NS, Sharma RK, Sharma N, Multani LS. Multiple myeloma presenting as proptosis and sixth nerve palsy. J Assoc Physicians India. 2001;49:1116-1117.

12. Durie BG, Salmon SE. A clinical staging system for multiple myeloma. Correlation of measured myeloma cell mass with presenting clinical features, response to treatment, and survival. Cancer. 1975;36(3):842-854.

13. Park MS, Kim BC, Kim IK, Lee SH, Choi SM, Kim $\mathrm{MK}$, Lee SS, et al. Cerebral infarction in $\mathrm{IgG}$ multiple myeloma with hyperviscosity. J Korean Med Sci. 2005;20(4):699-701.

14. Coull BM, Beamer N, de Garmo P, Sexton G, Nordt F, Knox R, Seaman GV. Chronic blood hyperviscosity in subjects with acute stroke, transient ischemic attack, and risk factors for stroke. Stroke. 1991;22(2):162-168.

15. Jones MM, Clemant CI, Rowe DB. Isolated trochlear nerve palsy as a presenting feature of primary polycythemia rubra vera. Clin Experiment Ophthalmol. 2004;32 (3):339-340.

16. Sanders SK, Kawasaki A, Purvin VA. Long-term prognosis in patients with vasculopathic sixth nerve palsy. Am J Ophthalmol. 2002;134(1):81-84.

17. Asbury AK, Aldredge H, Hershberg R, Fisher CM. Oculomotor palsy in diabetes mellitus: a clinico-pathological study. Brain. 1970;93(3):555-566.

18. Alkner U, Hansson UB, Lindstrom FD. Factors affecting IgA related hyperviscosity. Clin Exp Immunol. 1983;51(3):617-623. 